Artigo original

Hegemonia - Revista Eletrônica de Relações Internacionais do Centro Universitário Unieuro

ISSN: 1809-1261

UNIEURO, Brasília, número 21, Julho-Dezembro de 2017, pp. 154-194.

Recebido em: 26/3/2017

Avaliado em 12/4/2017

Aprovado em: 18/5/2017

\title{
A importancia das ações afirmativas no Brasil: O caso das cotas raciais de acesso à Universidade
}

Kellen Carolina Miranda Prodígios ${ }^{1}$

RESUMO: Este trabalho tem por escopo a análise da aplicabilidade prática e a efetividade do critério utilizado para aferir o merecimento das cotas raciais de acesso à Universidade, à luz dos princípios da dignidade da pessoa humana e da igualdade, plasmados na Constituição da República Federativa do Brasil de 1988. Ressaltaremos a história dos afro-descendentes no Brasil, desde sua chegada motivada pela necessidade de mão-de-obra nos engenhos, bem como o status de escravo, as leis abolicionistas que contribuíram para o fim da escravidão e sua posição na sociedade atual, a fim de verificar a real necessidade da política de cotas. Apontaremos os indicadores sociais denotam a diversidade racial e étnica existente no país, a qual colabora para a miscigenação, e ainda a discriminação racial e o racismo camuflado, norteador da ideia de democracia racial. Analisaremos o surgimento das Ações Afirmativas, seus objetivos, as modalidades existentes, principalmente seus fundamentos constitucionais, bem como os alicerces principiológicos, quais sejam a igualdade e a dignidade da pessoa humana, e sua consolidação no ordenamento jurídico brasileiro.

Palavras-chave: Brasil; Ações afirmativas; Cotas raciais.

RESUMEN: Este trabajo tiene como objetivo analizar la aplicabilidade práctica y la efectividad del criterio utilizado para asignar el merecimiento de cuotas raciales dentro la universidad, a la luz de los principios de dignidad de la persona humana y de la igualdad, plasmados en la Constitución de la República federativa de Brasil de 1988. Resaltamos la historia de los afrodescendientes en Brasil desde su arribo motivado por la necesidad de mano de obra en los ingenios de caña de azúcar, así como el status de esclavo, las leyes abolicionistas que contribuyeron para el fin de la esclavitud y su posición en la sociedad actual, a fin de verificar la real necesidad de la política de cuotas. Apuntaremos como los indicadores sociales denotan la diversidad racial y étnica existente en el país, la cual colabora para el mestizaje, ella aún la persistente discriminación camuflada, norteadora de la idea de democracia racial. Analizaremos el surgimiento de las acciones afirmativas, sus objetivos, las modalidad existentes, principalmente sus fundamentos constitucionales, bien como los andamios principiológicos cuales sean igualdad e dignidad de la persona humana y su consolidación en el ordenamiento jurídico brasileño.

Palabras-clave: Brasil; Acciones afirmativas; Cuotas raciales.

\footnotetext{
${ }^{1}$ Advogada e Pós-graduanda em Direito Civil. Especialista em Direitos Humanos.
} 
Artigo original

Hegemonia - Revista Eletrônica de Relações Internacionais do Centro Universitário Unieuro ISSN: $1809-1261$

UNIEURO, Brasília, número 21, Julho-Dezembro de 2017, pp. 154-194.

\section{CONTEXTO HISTÓRICO}

A terminologia Afro-descendente foi utilizada no presente trabalho, em decorrência da divergência quanto à classificação da cor da pele ou raça da população. No dizer de Ricardo Franklin Ferreira, "afro-descendente é uma categoria que inclui tanto as pessoas consideradas negras como as consideradas mestiças ${ }^{2}$

Programa das Nações Unidas para o Desenvolvimento utiliza desse termo para verificar o Índice de Desenvolvimento Humano entendendo que afrodescendentes englobam negros e pardos.

Da mesma forma, estribado na obra de Ferreira, o Brasil possui cerca de 44,3\% da população de origem Africana. Porém, como a sociedade brasileira impõe a ïideologia do branqueamento" faz com que a maioria das pessoas omita os traços de origem negra. ${ }^{3}$ De tal sorte, tais dados não condizem com a realidade da população étnico brasileira, podendo ser mais alto o índice de afro-descendentes existentes em nosso país, por formarem um grupo com contingente de quase metade ou mais da população brasileira.

Em verdade, o Brasil foi o país que mais escravizou negros, o último a abolir a escravidão e mesmo assim foi visto como a primeira "democracia racial" do mundo entre os anos de 1900 a 1950. No Brasil, há previsão legal garantidora da igualdade de todos perante a lei, sem distinção de qualquer natureza e eleva a condição de racismo como crime inafiançável e imprescritível, por assim perpetuar em gerações, consoante o artigo 5o, Caput e inciso XLII, da Constituição da República Federativa do Brasil.

2 FERREIRA, Ricardo Franklin. Afro-descendente: identidade em construção. São Paulo: Educ e Rio de Janeiro: Pallas, 2004, p. 50.

${ }^{3}$ dem, op. cit., p. 39. 
Artigo original

Hegemonia - Revista Eletrônica de Relações Internacionais do Centro Universitário Unieuro ISSN: $1809-1261$

UNIEURO, Brasília, número 21, Julho-Dezembro de 2017, pp. 154-194.

A contrário Sensu, no Sul dos Estados Unidos e África do Sul, a discriminação é explícita e institucionalizada por lei, o que fez com que os afrodescendentes valorizassem sua cultura africana e desenvolvesse um sentido de grupo, passando a encarar o preconceito existente.

Quanto à diversidade e identidade étnica no Brasil, o desenvolvimento da população brasileira está intimamente ligado a participação dos africanos, que se manifestam na cultura, nos gestos e nas relações. A Igreja Católica foi a "grande agência legitimadora" das práticas discriminatórias ao homem africano, que foi associado a qualidades negativas pelo homem europeu, antes mesmo do descobrimento do Brasil e da colonização.

Contudo, a qualidade negativa atribuídas à cultura africana gera aos afro-descendentes um complexo de inferioridade e sua consequente exclusão da sociedade, e ao homem europeu denominado branco, a "perspectiva do direito de dominar". Assim, começa a luta dos afrodescendentes contra a discriminação racial, um problema norteador da desigualdade social e econômica que aflige as minorias raciais da sociedade atual.

\section{A ESCRAVIDAO NO BRASIL}

$\mathrm{Na}$ escravidão o homem é transformado em propriedade do outro, com isso seu querer é anulado, "O escravo pode ter vontades, mas não pode realizá-las ${ }^{* 4}$ A primeira experiência portuguesa com a mão-de-obra escrava deu-se a partir de 1441, com o regresso de uma expedição do Rio do Ouro, onde capturaram seis homens na costa do Saara, na África, para D. Henrique ${ }^{5}$.

Nessa época, a população de Portugal estava debilitada em decorrência da guerra de independência contra Castela, a epidemias que alastraram em seu território, e pelo deslocamento de mão-de-obra para a África e as Índias. Neste sentido, os escravos eram uma medida viável para compensar a perda populacional e garantir as "conquistas ultramarinas".

\footnotetext{
${ }^{4}$ PINSKY. Jaime. A Escravidão no Brasil. 18a ed. São Paulo: Contexto, 2001, p. 11

${ }^{5}$ PINSKY. Jaime, op. cit., p. 13.
} 
Artigo original

Hegemonia - Revista Eletrônica de Relações Internacionais do Centro Universitário Unieuro ISSN: $1809-1261$

UNIEURO, Brasília, número 21, Julho-Dezembro de 2017, pp. 154-194.

Inicialmente, as expedições portuguesas iam atrás de riquezas na costa noroeste da África, e a aquisição dos escravos, através do rapto constituía uma de várias tarefas dos lusitanos. Em 1444, os portugueses saiam especificamente para capturar escravos. Quando voltaram a Portugal, com os prisioneiros, entre mulatos, negros e brancos, recepcionados com entusiasmo, os sentimentos dos escravos contrastavam uns com outros, uns lamentavam, outros ficavam cabisbaixos e outros se autoflagelando.

A origem da escravidão no Brasil se deu com a descoberta do país pelos Portugueses. Um dos elementos justificadores do escravismo português no Brasil era o "caminho da salvação espiritual", que a conversão ao cristianismo lhes propiciava, vista como forma de compensação das agressões físicas e a privação da liberdade. Com o tempo, surgiu "negro-mercadoria", através de uma organização no forte português, no qual comercializavam negros cativos buscados do interior da África.

A primeira mão-de-obra utilizada no Brasil foi a indígena, através do sistema de trocas de paubrasil e alimentos portugueses. Porém, com o tempo, o escambo tornou-se inviável para os comerciantes lusitanos, daí surgiu a escravização do índio. A resistência dos índios em serem escravizados, a fraca densidade da população indígena, decorrentes da super exploração e a proteção jesuítica, foram fatores responsáveis para o fim da escravidão indígena no Brasil.

A ausência de mão-de-obra suficiente e de baixo custo operacional nas grandes lavouras foi condição sine qua non para que os negros fossem trazidos da África para o Brasil. Contudo, o negro foi trazido para o país, para desempenhar o trabalho compulsório em função do projeto da grande lavoura, que consiste em produzir gêneros para Portugal.

O transporte de escravos através do tráfico negreiro demonstra o tratamento desumano e degradante aos quais os negros eram submetidos. O desembarque ocorria logo em seguida à chegada aos portos no Nordeste, Norte ou no Rio de Janeiro, e ao mesmo tempo, acontecia à venda de escravos através de negociação ou leilões. Equiparado a mercadoria, os negros eram examinados como animais no momento da venda, separados de suas famílias quando não 
Artigo original

Hegemonia - Revista Eletrônica de Relações Internacionais do Centro Universitário Unieuro ISSN: $1809-1261$

UNIEURO, Brasília, número 21, Julho-Dezembro de 2017, pp. 154-194.

havia interesse em adquirir todos os membros, não importando com seus sentimentos de seres humanos.

Entretanto, com a proibição do tráfico em 1850 as viagens e o comércio interno de escravos ficaram difíceis, ocorrendo o início do contrabando. Os negros eram submetidos a tratamento humilhante, em todos os setores da vida. Com relação ao trabalho nas fazendas de café, tinham jornadas de trabalho que variavam de quinze a dezoito horas diárias, iniciando na madrugada. $\mathrm{Na}$ época eram tão desvalorizados, pois é comum documentos antigos tecerem reclamações pelos senhores do café se referindo aos negros como preguiçosos.

Quanto à moradia, viviam em senzalas, habitações coletivas construídas de pau-a-pique, cobertas de sapé. Algumas tinham divisões internas e mobiliário antigo, usavam cobertores e travesseiros em palha para se aquecerem. No vestuário, as roupas eram feitas de um tecido grosso composto de calça, camisa e um colete longo, já as mulheres usavam saia e blusa de chita.

No que tange a religião, o escravo era obrigado a abandonar sua fé de origem africana e adotar o catolicismo. Assim, ao chegarem ao local de trabalho eram batizados e recebiam um nome cristão. No que se refere à repressão sofrida pelos negros, a legislação portuguesa e imperial sempre procurou evitar abusos por parte dos senhores ao repreender os escravos, a fim de evitar que os negros, além de serem tolhidos de sua liberdade, fossem também maltratados.

O sistema escravista, buscando preservar a força de trabalho, permitia práticas de coação física para que o escravo cumprisse com seus deveres. Porém, havia leis, portarias e recomendações que proibiam os castigos desproporcionais às irregularidades cometidas pelos escravos. Quanto aos castigos sofridos pelos escravos, havia inúmeras formas, tais como: correntes, tronco, algema, peia, máscara de Flandes, palmatória, ferro para marcar, calabouço. A Máscara de Flandes era de metal flexível, geralmente zinco, cobria todo o rosto, só o nariz e os olhos, eram liberados com pequenos furos, foi utilizada para coibir a ingestão de alimentos ou bebidas pelo escravo, na Zona Aurífera, servia para que o escravo não ingerisse nenhuma pedra preciosa ou pepita de ouro. $\mathrm{O}$ açoite era o castigo mais comum dado aos escravos. 
Artigo original

Hegemonia - Revista Eletrônica de Relações Internacionais do Centro Universitário Unieuro ISSN: $1809-1261$

UNIEURO, Brasília, número 21, Julho-Dezembro de 2017, pp. 154-194.

Utilizava-se uma vara de marmelo ou uma madeira flexível. Há alguns registros de morte de escravos em decorrência do excesso de açoite.

$\mathrm{Na}$ época da escravidão, a situação jurídica dos escravos era totalmente adversa do branco, para os negros havia pena de morte do tipo enforcamento, quando feriam ou assassinavam seus senhores, familiares ou feitores, sua sentença não tinha direito de recurso ao Imperador, que detinha poder moderador, de perdoar ou moderar as sentenças. A população começou a se conscientizar da violência praticada contra os negros com as leis de 1850, que proibiam o tráfico negreiro.

Os escravos fujões eram capturados e tinham suas cabeças decepadas para servirem de exemplo. Com as fugas, alguns escravos ficavam ao redor das fazendas de origem em busca de comida, roupa e companhia, porque não tinham para onde ir, e sua cor de pele logo declarava que ele era escravo, outros escravos, refugiavam-se em quilombos, nos quais podiam praticar sua cultura e rituais africanos.

Os Quilombos eram a saída para conseguir a real liberdade. Os Quilombos formavam-se rapidamente, e tinha duração passageira, alguns eram destruídos por capitães-do-mato, que procuravam os escravos fujões, outros ganhavam grande importância, como Palmares. Tornar-se capitão-do-mato era uma forma dos negros romperem a barreira étnico-social e usufruir do sistema que o oprimiu.

O Quilombo de Palmares foi constituído na região Nordeste do país, na Serra da Barriga, atual estado de Alagoas. Era um dos maiores da época, formado por uma população de vinte mil habitantes, organizado sob a forma de reino, um verdadeiro estado dentro de outro, teve duração de 67 anos. Quanto à organização, Palmares era governado por um rei, Ganga Zumba, que quer dizer grande chefe, e um Conselho composto por mocambos, eleito pelos habitantes através de assembleia.

A mantença do Quilombo advinha da caça, pesca, agricultura e artesanato. Tinha uma economia estável e contatos comerciais com as vilas mais próximas. A extinção de Palmares 
Artigo original

Hegemonia - Revista Eletrônica de Relações Internacionais do Centro Universitário Unieuro ISSN: $1809-1261$

UNIEURO, Brasília, número 21, Julho-Dezembro de 2017, pp. 154-194.

deu-se em virtude dos constantes ataques organizados por milícias de fazendeiros que temiam a fuga de mais escravos. Então, Zumba fez um acordo com os fazendeiros, e os quilombolas inconformados o envenenaram.

A partir daí, seu sobrinho, Zumbi assumiu seu lugar e encabeçou a luta contra os fazendeiros. Porém, aos poucos, o quilombo foi tomado e quedou. Inconformados com a situação vivida, os escravos se rebelavam. Em 1813, mais ou menos seiscentos negros atacaram todos os brancos que estavam no caminho de Itapuã, perto de Salvador.

Em 1835, vários negros ocuparam durante horas, ruas e edifícios públicos em Salvador. Em 1838 no Maranhão e Piauí, ocorreu a Revolta da Balaiada, um dos mais conhecidos levantes de escravos, que resistiram às tropas do Governo por três anos. No Rio, Espírito Santo e em São Paulo, houve vários levantes de escravos.

Diante do tratamento desumano sofrido pelos negros, e a falta de perspectiva de vida, os negros começaram a se auto-eliminar com a prática de suicídio, as formas eram através de asfixia, enforcamento, veneno, arma branca, arma de fogo. Enfim, o inconformismo dos escravos demonstrado em gestos como suicídio, fugas, assassinatos e rebeliões justifica a contribuição dos negros em sua libertação.

Em 1886, criou-se uma Lei que proibiu o açoite, em decorrência de 2 escravos serem mortos, após cumprirem pena de 300 açoites. Por fim, em 13 de maio de 1888, foi sancionada a Lei Áurea que proibiu a escravidão em todo território nacional. Entretanto, a condição econômica e social dos negros não modificou, pois sem estudo e sem formação profissional, não teriam como conseguir uma ascensão social.

\section{A DISCRIMINAÇAO RACIAL NO BRASIL}

Consoante o texto da Convenção Internacional sobre a Eliminação de Todas as formas de Discriminação Racial, na qual o Brasil é signatário, a expressão Discriminação Racial significa: 
Artigo original

Hegemonia - Revista Eletrônica de Relações Internacionais do Centro Universitário Unieuro ISSN: $1809-1261$

UNIEURO, Brasília, número 21, Julho-Dezembro de 2017, pp. 154-194.

qualquer distinção, exclusão, restrição ou preferência, baseadas em raça, cor, descendência ou origem nacional ou étnica que têm por objetivo ou efeito anular ou restringir o reconhecimento, gozo ou exercício em um mesmo plano (em igualdade de condição) de direitos humanos e liberdades fundamentais no domínio político, econômico, social, cultural ou em qualquer outro domínio de vida pública.. 6

Assim, a partir dessa definição depreende-se que a discriminação é aqui é exposta em sentido amplo e não detém um rol taxativo, e possui um caráter negativo de reprovação, rejeição.

Seguindo a linha de raciocínio de Joaquim B. Barbosa Gomes, ministro do Supremo Tribunal Federal, acreditamos que a discriminação pode ser classificada em não intencionais e intencionais explícitas ou implícitas ${ }^{7}$. Nesse sentido, as discriminações não intencionais ou discriminações de fato decorrem da omissão ou inércia do Poder Público mediante a distorção do conceito de igualdade, a qual enfatiza a igualdade formal e desmerece as políticas de inserção social aos grupos excluídos.

Nesse sentido, em virtude da ausência de implantação das ações afirmativas, as discriminações são vistas como normais pela sociedade, de forma inconsciente e camuflada, e pode ser expressada como discriminação cordial.

Assim sendo, as discriminações intencionais explícitas são verificadas no primeiro momento de análise, geralmente são ilícitas e exsurgem quando determinado grupo de pessoas recebem tratamento diverso de outro grupo em razão de sua raça, cor, religião dentre outros. Outrossim, as discriminações intencionais implícitas podem se manifestar por uma norma

\footnotetext{
${ }^{6}$ Parte I, art. 1o, \$1 da Convenção Internacional sobre a Eliminação de Todas as formas de Discriminação Racial. Disponível em: $<$ http://www.mj.gov.br/sedh/ct/legis_intern/conv_int_eliminacao_disc_racial.htm $>$. Acesso em: 02 de setembro de 2008.

7 GOMES. Joaquim Benedito Barbosa. Ação Afirmativa e principio Constitucional da Igualdade. Rio de Janeiro: Renovar, 2001. p. 20.
} 
Artigo original

Hegemonia - Revista Eletrônica de Relações Internacionais do Centro Universitário Unieuro ISSN: $1809-1261$

UNIEURO, Brasília, número 21, Julho-Dezembro de 2017, pp. 154-194.

legislativa mal elaborada que posteriormente será submetida ao controle de constitucionalidade.

Nesse compasso, a referida discriminação vem à tona no ato de aplicação da norma, quando é demonstrada a preferência de determinado grupo em detrimento de outro. Pode ocorrer, ainda, a discriminação intencional implícita através da camuflagem do real sentido da norma, apesar de não estar declarada a intenção discriminatória.

Para a compreensão do contexto a ser analisado, faz-se necessário alguns esclarecimentos pertinentes à discussão.

A população do Brasil é composta por descendentes de indígenas, portugueses, africanos e imigrantes, vindos de Portugal e Itália, e ainda Alemanha, Espanha, Japão e Síria Libanesa. Existem inúmeros sistemas de classificação de cor, os quais apontam diversidades.

O Instituto Brasileiro de Geografia e Estatística distingue a população nas classes branco, preto, pardo, amarelo e indígena. As origens étnicas do processo civilizatório brasileiro utilizam as classes negro, branco e índio. No Censo Demográfico do ano de 1980, a classificação popular definiu 136 categorias de cores. Os pesquisadores de ciências humanas utilizam-se do sistema bipolar branco e não-branco. O Movimento Negro usa a terminologia branco e negro.

O processo de identificação racial brasileiro é complexo, em razão da percepção dos indivíduos divergirem entre si. Como exemplo, temos as pessoas mestiças, com leves características de pessoa negra, porém com condição econômica elevada ser considerado branco. Há ainda, o fato de pessoas brancas que participam da cultura negra, no entanto, se consideram como negras, justamente em virtude de terem um contato maior com esse grupo.

Atualmente, há uma discussão acadêmica no que tange raça ou cor no Brasil, e o texto clássico de Oracy Nogueira, constitui uma das principais referências pertinentes a discussão acadêmica. Segundo o autor, nos Estados Unidos há o preconceito de origem, o qual para definir a pessoa 
Artigo original

Hegemonia - Revista Eletrônica de Relações Internacionais do Centro Universitário Unieuro ISSN: $1809-1261$

UNIEURO, Brasília, número 21, Julho-Dezembro de 2017, pp. 154-194.

como sendo negra, é analisado sua ascendência africana ou escrava. Já no Brasil, o preconceito

de marca, é visto através da cor da pele da pessoa, não importando sua origem. ${ }^{8}$

Sob o prisma da Escola Paulista, liderada por Florestan Fernandes, o preconceito de raça é um preconceito de classe, em razão de seu enriquecimento ou não. Neste sentido, a questão racial seria resolvida na medida em que a desigualdade social for solucionada. ${ }^{9}$

De acordo com Nogueira, nos Estados Unidos a diferença racial não desapareceria nem com o branqueamento da população, nem com a eliminação da desigualdade social. Entretanto, no Brasil, a desigualdade racial é marcada pela falsa consciência, impedindo a população de entender o problema vivido.

Desta maneira, nas pesquisas realizadas pelo Instituto Brasileiro de Geografia e Estatística, nas quais o critério cor tem as categorias branco, preto, pardo, amarelo e indígena, os pretos e pardos deveriam ser englobados na categoria negros ou afro-descendentes. ${ }^{10}$

O Instituto Brasileiro de Geografia e Estatística, ao realizar a Pesquisa Mensal de Emprego de julho de 1998, incluiu questões abertas para comparar as respostas a pergunta tradicional sobre cor, objetivando verificar se a forma pela qual a população brasileira se identifica está de acordo com as origens culturais e étnicas específicas, bem como o preto ou pardo, se classifica como negro ou afro-descendente, e o branco se identifica como sendo de outra cultura ou etnia. ${ }^{11}$

Os resultados confirmaram que no Brasil não há delimitação entre a população no que se refere a características étnicas, linguísticas, culturais ou históricas, por isso, conclui-se que classificar as pessoas de acordo com essas categorias denota imprecisão. Porém, o assunto pode ser pesquisado conforme dados estatísticos, mesmo sendo de delimitação pouco nítida, pois permite os esclarecimentos da realidade. Desta feita, o sistema de classificação racial no

${ }^{8}$ NOGUEIRA, Oracy. Tanto Preto quanto branco etudi de Relações Raciais. São Paulo: T. A. Queiroz. 1.985. pp. 67-93.

${ }^{9}$ FERNANDES. Florestan. BRASIL. Campinas: Universidade Estadual de Campinas, Núcleo de Estudos de População. 1.986. p. 59.

${ }^{10}$ SCHWARTZMAN, Simon. Fora de Foco: Diversidade e Identidades étnicas no Brasil. Novos Estudos CEBRAP, no. 55, pp. 83-96. p. 3, 1999, Disponível em: http://www.schwartzman.org.br/simon/pdf/origem.pdf> . Acesso em: 02 de setembro de 2008.

${ }^{11}$ Idem, ibidem 
Artigo original

Hegemonia - Revista Eletrônica de Relações Internacionais do Centro Universitário Unieuro ISSN: $1809-1261$

UNIEURO, Brasília, número 21, Julho-Dezembro de 2017, pp. 154-194.

Brasil é caracterizado pela multirracialidade, pois entre brancos e negros há várias raças surgidas pela miscigenação.

É crucial a distinção de preconceito, discriminação racial e racismo, em razão do eufemismo empregado pela sociedade ao usar essas nomenclaturas. Até no final do século XVIII a teologia serviu de alicerce para o racismo no Brasil, consequentemente, os grupos de judeus, negros e indígenas eram discriminados como falsos cristãos, adversários da Igreja e vistos como ameaça à fé e aos bons costumes da época. O racismo antijudáico era fundamentado na tradição cristã católica e o racismo contra os negros, estribado na escravidão colonial.

O negro e o mestiço nunca conseguiam igualar ao homem branco. No dizer de Maria Luiza Tucci Carneiro, "O mundo da senzala sempre esteve muito distante do mundo da casa-grande. Em decorrência do homem branco portar o padrão de beleza e de moral, os negros independente da posição, escravo ou homem livre, para ter privilégios, era preciso esconder ou disfarçar seus traços africanos.

Alguns historiadores e sociólogos disfarçam a escravidão bestial e traiçoeira como se fosse amena e a fundamentam no tratamento humano recebido pelos escravos. Entretanto, a escravidão deixou feridas na alma dos afro-descendentes que transcende gerações. A escravidão branda defendida por alguns, reforça o mito da democracia racial ${ }^{12}$ que encobre o racismo no país.

Mesmo com a Abolição da Escravatura no Brasil, os negros não conseguiram desamarrar da posição ora ocupada, lhes foi dado apenas à ideia de liberdade, mas não condições para ascensão à nova ordem social. Eles não tinham outra opção a não continuar vivendo como servos do homem branco. Criativos, improvisavam e vendiam cestos, galinhas, doces, tabaco, trabalhavam de guias dos viajantes estrangeiros que vinham estudar o Brasil.

12 FERREIRA, op. cit., p. 39. Foi utilizado o termo "Mito da Democracia Racial" porque o Brasil foi o país que mais escravizou negros, o último país a abolir a escravidão e é visto como o primeiro país a adotar a democracia racial. Além de a convivência entre brancos e negros ser descrita como harmoniosa e igualitária. Nesse sentido há uma ironia, sendo questionada pela população brasileira. 
Artigo original

Hegemonia - Revista Eletrônica de Relações Internacionais do Centro Universitário Unieuro ISSN: $1809-1261$

UNIEURO, Brasília, número 21, Julho-Dezembro de 2017, pp. 154-194.

O branqueamento, através da miscigenação com o branco foi uma das saídas encontradas pelo negro para alcançar uma condição social superior, pois a pele clareava e ao alisar os cabelos, parecia-se mais com o ideal de beleza branca.

Com a chegada dos imigrantes ao Brasil, o homem negro foi visto como atraso, responsável pela desordem social e pelo crime, todavia o imigrante europeu era símbolo do desenvolvimento, valorizado como mão-de-obra mais eficiente.

A Constituição da República Federativa do Brasil promulgada em 1988 trouxe inúmeras previsões que desabonam o preconceito e o racismo, e apregoa a igualdade entre os indivíduos, como objetivo e valor fundamental do Estado Democrático de Direito. No preâmbulo da Carta Magna, o legislador expôs dentre os valores supremos de uma sociedade fraterna, pluralista e sem preconceitos a igualdade. ${ }^{13}$

Em 1993, o Governo de São Paulo criou a Delegacia Especializada em Crimes Raciais, competente para apurar infrações resultantes de discriminação ou preconceito de raça, cor, etnia e religião. Nesse sentido, o Constituinte caracterizou o ideal de sociedade almejada como sendo sem preconceitos. Porém, nossa realidade é diversa, cite-se abaixo alguns casos recentes de racismo noticiados pela mídia contra afro-descendentes.

Em 2005, durante uma partida de futebol entre os times São Paulo e Quilmes da Argentina ocorreu um caso de racismo que envolveu os jogadores Grafite e Desábato. ${ }^{14}$ Durante o jogo, Grafite se desentendeu com o jogador Arano em virtude de uma entrada brusca no argentino. Em seguida, Desábato ofendeu Grafite com palavras de cunho discriminatório.

Segundo Hélio Silva Junior, representante da Comissão de Direitos Humanos da OAB, o argentino declarou a discriminação feita em desfavor de Grafite: "Ele chamou grafite de

13 BRASIL. Constituição (1988). Preâmbulo.

${ }^{14}$ SILVA. Carlos Alberto Figueiredo da. Revista Digital Buenos Aires, no 84, 2005. Centro

Universitário Augusto Motta. Disponível em:< http://www.efdeportes.com/efd84/racismo.htm> . Acesso em: 18 de setembro de 2008. 
Artigo original

Hegemonia - Revista Eletrônica de Relações Internacionais do Centro Universitário Unieuro ISSN: $1809-1261$

UNIEURO, Brasília, número 21, Julho-Dezembro de 2017, pp. 154-194.

macaco, negrinho e mandou enfiar a banana em um lugar do corpo que eu não posso repetir

para vocês agora ${ }^{\cdot 15}$ nítido que o gesto do ofensor foi tomado de racismo em decorrência da cor de origem afro- descendente do jogador.

Esse ato é uma afronta aos direitos e garantias fundamentais dos indivíduos, protegidos pela Constituição Federal, qual seja a inviolabilidade à igualdade e a prática do racismo ser crime inafiançável e imprescritível.

Em 2006, outro caso de racismo que repercutiu internacionalmente foi o caso da doméstica, Simone Andréa Diniz, impedida de concorrer a uma vaga de emprego em razão de ser de origem afro-descendente. Ela viu o anúncio no jornal sobre uma vaga na função de doméstica, mas continha restrições que a pessoa deveria ser de preferência branca. Assim, a vítima ligou para o número indicado e foi surpreendida pela confirmação da exigência e pela declaração da empregadora que ela não preenchia os requisitos em face de sua cor.

Todavia, ao ser questionada pela preferência de cor branca no inquérito policial, a anunciante disse ter tido uma experiência desastrosa com uma empregada negra que maltratou seus filhos. Outrossim, com a conclusão do inquérito ninguém foi responsabilizado e consequentemente foi arquivado.

Assim, a Organização Interamericana de Direitos Humanos da Organização dos Estados Americanos condenou o Brasil por violar a Convenção Americana de Direitos Humanos e a Convenção Racial por arquivar um caso de racismo sem promover Ação Penal.

Recentemente, o coordenador do curso de Medicina da Universidade Federal da Bahia, Antônio Dantas, fez uma declaração discriminatória e racista, ao ser entrevistado sobre o mau desempenho dos alunos na avaliação do Enade. Ao ser questionado, Dantas atribui o resultado ao baixo QI (quociente de inteligência) dos baianos“ mencionando também que "o berimbau

\footnotetext{
15 DIÁRIO DO VALE. Argentino teria assumido declarações racistas. São Paulo. Diário On Line Esporte. Disponível em:<http://www.diarioon.com.br/arquivo/4036/esportes/esportes- 32531.htm>. Acesso em: 18 de setembro de 2008.
} 
Artigo original

Hegemonia - Revista Eletrônica de Relações Internacionais do Centro Universitário Unieuro ISSN: $1809-1261$

UNIEURO, Brasília, número 21, Julho-Dezembro de 2017, pp. 154-194.

é um instrumento para quem tem poucos neurônios, pois só tem uma corda ${ }^{*} \cdot{ }^{16}$ Com isso, o dirigente atacou a cultura baiana e seus costumes. Além de referir a política de cotas como a vilã causadora do resultado negativo e ao Olodum, como primariedade musical.

É notório que o caso supracitado denota uma atitude discriminatória contra os baianos, na grande maioria afro-descendentes, constitui atentado à política de inclusão social, além de contrariar os objetivos do Estado Democrático que é promover o bem de todos, sem preconceitos de origem, raça, sexo, cor, idade e quaisquer outras formas de discriminação. ${ }^{17}$

Diante disso, é explicita a necessidade de políticas públicas capazes de exterminar a discriminação racial existente no país, que vão além do conhecimento dos indivíduos, não escolhe condição econômica, nem cultural. O racismo no mundo globalizado não tem limites, ultrapassa os bons costumes, valores íntimos do individuo, a ética profissional e é aflorado quando se menos imagina.

Contudo, mesmo com a previsão legal e expressa do repúdio ao racismo, a discriminação está viva no seio da sociedade, separando os indivíduos e condenando pessoas de bem. ${ }^{18}$

Estudo elaborado pelo Professor Marcelo Paixão, Coordenador do Observatório Afrobrasileiro, demonstrou a desigualdade existente entre grupos étnicos brancos e afrodescendentes no Brasil. A pesquisa realizada teve como base os Indicadores de Desenvolvimento Humano, desenvolvido pelo Programa das Nações Unidas para o Desenvolvimento, e classificam os 174 países do mundo dentro de um ranking, que agrega: renda per capita, longevidade e alfabetização aliada à taxa de escolaridade.

\footnotetext{
16 VASCONCELOS. Adriana; TALENTO, Biaggio; FRAGA, Danilo. O Globo. Disponível em: $<$ http://www.adurrj.org.br/5com/pop-up/declaracao_qi_do_baiano.htm>. Acesso em: 18 de setembro de 2008.

17 BRASIL. Constituição (1988). Art. 3o. "Constituem objetivos fundamentais da República Federativa do Brasil: IV promover o bem de todos, sem preconceitos de origem, raça, sexo, cor, idade e quaisquer outras formas de discriminação" 18 BRASIL. Constituição (1988). $\square$ Art. 4o. "A República Federativa do Brasil rege-se nas suas relações internacionais pelos seguintes princípios: VIII - repúdio ao terrorismo e ao racismo.
} 
Artigo original

Hegemonia - Revista Eletrônica de Relações Internacionais do Centro Universitário Unieuro ISSN: $1809-1261$

UNIEURO, Brasília, número 21, Julho-Dezembro de 2017, pp. 154-194.

O trabalho realizado aplicou o mesmo método do Programa das Nações Unidas para o Desenvolvimento, para pesar as disparidades entre brancos e afro-descendentes, considerou como afro-descendentes, os negros e pardos do país.

No entendimento do Professor Marcelo Paixão, o Índice de Desenvolvimento Humano tem importância crucial na construção de políticas públicas dentro dos países,

A tabela abaixo, demonstra as disparidades étnicas existentes entre brancos e afrodescendentes, apuradas pelo Programa Nacional de Amostras por Domicílios em 2.002, senão vejamos:

\begin{tabular}{|c|c|c|}
\hline \multicolumn{2}{|c|}{ Indicadores Raciais } \\
\hline Itens & Brancos & Negros \\
\hline Composição da População Total & $54 \%$ & $45,3 \%$ \\
\hline Proporção de Pobres & $22 \%$ & $45 \%$ \\
\hline Proporção de Indigentes & $7,8 \%$ & $19,5 \%$ \\
\hline Rendimento Médio do Trabalho & $\mathrm{R} \$ 697,00$ & $\mathrm{R} \$ 341,00$ \\
\hline Taxa de Desemprego & $8,2 \%$ & $10,3 \%$ \\
\hline Analfabetismo de maiores de 15 anos & $7,5 \%$ & $17,2 \%$ \\
\hline Escolaridade Média & 7 anos & 4,9 anos \\
\hline Crianças em Atraso Escolar & $9,6 \%$ & $22,3 \%$ \\
\hline Lares com Serviço de Esgoto Adequado & $76,5 \%$ & $55,5 \%$ \\
\hline Lares com Água Encanada & $87,7 \%$ & $62,7 \%$ \\
\hline
\end{tabular}

Fonte: Pesquisa Nacional de Amostra Por Domicílios - PNAD - 2002 
Artigo original

Hegemonia - Revista Eletrônica de Relações Internacionais do Centro Universitário Unieuro ISSN: $1809-1261$

UNIEURO, Brasília, número 21, Julho-Dezembro de 2017, pp. 154-194.

O Brasil, segundo o Relatório de Desenvolvimento Humano de 2007/2008, ocupa a 70a posição no ranking, dentre os países de Desenvolvimento Humano Elevado. Estudos do Instituto de Pesquisa Econômica Aplicada, baseados em dados do Instituto Brasileiro de Geografia e Estatística, revelaram que ainda em 2008 a população parda e negra será maioria o Brasil, porém as desigualdades de serviços, bens e direitos fundamentais permanecerá. ${ }^{19}$

O mesmo estudo demonstra ainda, que para haver equiparação salarial entre negros e braços demorariam cerca de 32 anos. Assim, fica claro a disparidade existente entre o branco e o afrodescendente do Brasil, sendo a etnia um fator determinante para sua condição econômica e social.

\section{AÇOES AFIRMATIVAS}

Ações afirmativas são políticas públicas ou privadas voltadas à equiparação dos indivíduos desiguais, e que em razão dessas diferenças são discriminados de forma negativa pela sociedade. É chamada também de ação positiva ou discriminação positiva, pois a discriminação nesse caso é para igualar as diferenças, e não para ofendê-los. A expressão requer um conceito técnico, entendemos ser Joaquim B. Barbosa Gomes o que melhor exprime o significado, aduzindo que:

“Consistem em políticas públicas (e também privadas) voltadas à concretização do princípio constitucional da igualdade material e à neutralização dos efeitos da discriminação racial, de gênero, de idade, de origem nacional, de compleição física e situação socioeconômica ( adição nossa). Impostas ou sugeridas pelo Estado, por seus entes vinculados e até mesmo por entidades puramente privadas, elas visam a combater não somente

19 O ESTADO DE SÃO PAULO. Negros serão maioria já em 2008, diz Instituto de Pesquisa Econômica e Aplicada. São Paulo: 14 de m aio de 2008. Disponível em:<http://pfdc.pgr.mpf.gov.br/clipping/maio/negros-serao-maioria-no-pais-jaem-2008-diz- ipea/>. Acesso em: 16 de setembro de 2008. 
Artigo original

Hegemonia - Revista Eletrônica de Relações Internacionais do Centro Universitário Unieuro ISSN: $1809-1261$

UNIEURO, Brasília, número 21, Julho-Dezembro de 2017, pp. 154-194.

as manifestações flagrantes de discriminação, mas também a discriminação de

fundo cultural, estrutural, enraizada na sociedade. ${ }^{20}$

As Ações Positivas originaram-se nos Estados Unidos, no mandato do Presidente John F. Kennedy, e posteriormente pelo Presidente Lyndon Johnson, motivadas na ideia da extensão da igualdade de oportunidades no mercado de trabalho. Têm por finalidade inserir a igualdade concreta, nesse caso, a igualdade material atingida através da busca de mecanismos que nivelem as desigualdades existentes, as quais a igualdade formal não consegue proporcionar.

As Ações Afirmativas podem existir em duas categorias, segundo os objetivos, como imediatos ou mediatos. Conforme o ensinamento de Enzo Bello, dentre os objetivos imediatos ressaltase: a inclusão das minorias através da igualdade de oportunidades e resultados nos estudos e no trabalho, inserção de representatividade dos excluídos nas atividades públicas ou privadas, em funções de comando ou chefia e o extermínio das glass ceiling ${ }^{21}$

Outrossim, com relação aos objetivos mediatos destaca-se a conscientização da sociedade a fim de extirpar o racismo ou vantagens oriundas de condição econômica abastada, instituição de Role Models e repartição de renda para as classes pobres.

Existem dois estágios anteriores ao surgimento da ação afirmativa, quais sejam a igualdade e a criminalização de práticas discriminatórias. Para a sua aplicação, geralmente são aliadas à estipulação de cotas, ou seja, reserva de vagas ou lugares a pessoas beneficiadas. ${ }^{22}$

\footnotetext{
${ }^{20}$ GOMES, op. cit., p. 6,7.

${ }^{21}$ BELLO. Enzo. Periódico n ${ }^{2}$ 26. Políticas Públicas para a População negra no Brasil. Rio de Janeiro: Pontifícia Universidade Católica - Departamento de Direito, janeiro-junho, 2005. p. 37. *ODVV $\square$ \&HLOLQJ são obstáculos artificiais e invisíveis, que impedem o crescimento pessoal e profissional de certos indivíduos discriminados em razão do preconceito quanto a sua etnia, gênero, idade, dentre outros. 22 MENEZES. Paulo Lucena de. A Ação Afirmativa. (Affirmative Action) no Direito Norte-Americano. São Paulo: Revista dos Tribunais, 2001. p. 30. Como exemplo, a Constituição Estadual da Bahia dispõe: "Art. 289 - Sempre que for veiculada publicidade estadual com mais de duas pessoas, será assegurada a inclusão de uma da raça negra".
} 
Artigo original

Hegemonia - Revista Eletrônica de Relações Internacionais do Centro Universitário Unieuro ISSN: $1809-1261$

UNIEURO, Brasília, número 21, Julho-Dezembro de 2017, pp. 154-194.

Quanto à duração, devem permanecer enquanto durarem as disparidades sociais, consoante o que dispõe o $\int 40$ do art. 10 da Convenção Internacional sobre a Eliminação de Todas as formas de Discriminação Racial, da Organização das Nações Unidas. ${ }^{23}$

Nesse compasso, vale ressaltar, as cotas constituem uma modalidade de ação afirmativa. Dentre as modalidades podem ser instituídos o método de estabelecimento de preferências, incentivos ou isenções fiscais ao poder público e estímulo ao mercado de trabalho no setor privado.

Nos Estados Unidos, a modalidade de ação afirmativa pelo método de cotas foi descartado por entenderem que aduz tratamento discriminatório em face das pessoas não pertencentes ao grupo beneficiado e ainda, por ser inconstitucional. As referidas ações são aplicadas não só no setor público, por iniciativas oficiais ou programas instituídos em lei, mas também no setor privado, através de cursos ministrados a determinados funcionários a fim de corrigir as falhas educacionais e permitir seu crescimento.

Imperioso esclarecer, as ações em epígrafe detém o condão de combater a desigualdade gerada por reiteradas práticas discriminatórias negativas, as quais expõe determinados grupos a condições inferiores aos outros. Tem como premissa o beneficiamento de grupos não pertencentes a posição dominante na sociedade, que esteja em desvantagem ou sofra discriminação.

Há uma discussão na doutrina no que se refere a essas ações serem concebidas sob duas concepções: forma de justiça compensatória ou distributiva. Consoante a primeira corrente, a justiça compensatória seria uma forma de ressarcimento dos danos causados a certos grupos pelo poder público ou empresas privadas.

23 A norma estabelece que: "Não serão consideradas discriminação racial as medidas tomadas com o único objetivo de assegurar progresso adequado de certos grupos raciais ou étnicos ou de indivíduos que necessitem de proteção que possa ser necessária para proporcionar a tais grupos ou indivíduos igual gozo ou exercício de direito humanos e liberdades fundamentais contanto que tais medidas não conduzam, em consequência, à manutenção de direitos separados para diferentes grupos raciais e não prossigam após terem sido alcançados os seus objetivos”. 
Artigo original

Hegemonia - Revista Eletrônica de Relações Internacionais do Centro Universitário Unieuro ISSN: $1809-1261$

UNIEURO, Brasília, número 21, Julho-Dezembro de 2017, pp. 154-194.

Assim, apenas os agressores, responsáveis pela discriminação devem ser penalizados e de outro somente os indivíduos discriminalizados, identificados um por um, devem ser ressarcidos proporcionalmente aos danos sofridos.

Outrossim, deve-se ater ao cuidado de não gerar uma discriminação reversa ${ }^{24}$, tornando essas políticas injustas, assim é mister identificar individualmente vítima e agressor, a fim de não punir nem beneficiar pessoas erradas, invertendo o foco principal dessas ações. Por outro lado, existem opiniões extremadas que defendem como forma de nivelamento das diferenças sociais, a adoção de discriminação reversa em face dos grupos inferiorizados.

alguns estudiosos entendem apenas a existência da desigualdade na sociedade como exemplo a condição inferiorizada dos afro- descendentes implicam a inserção de ações positivas. Em virtude da grande discussão e da dificuldade de lidar com essas ações, muitos ordenamentos jurídicos introduziram uma cláusula genérica em suas Constituições permitindo a inserção de ações afirmativas na sociedade.

No Brasil, a Constituição Federal prevê de forma pontual, a inclusão dessas ações na sociedade, como ocorre no caso da reserva de vagas para os portadores de deficiência. ${ }^{60}$ Contudo, a discriminação aos grupos marginalizados em nosso país é uma realidade, e necessita ser exterminada ou ao menos amenizada. Daí depreende-se a crucial importância da análise do instituto das Ações Afirmativas no direito brasileiro.

\section{AUTORIZAÇAO CONSTITUCIONAL PARA INSTITUIÇAO DE AÇOES AFIRMATIVAS}

A Constituição da República Federativa do Brasil de 1988 instituiu um Estado Democrático de Direito pautado na defesa dos direitos sociais e individuais, bem como na igualdade e justiça

\footnotetext{
${ }^{24}$ MENEZES, op. cit., p. 35. Discriminação reversa é uma expressão muito utilizada pelos opositores da ação afirmativa, nos Estados Unidos, sendo utilizada enfaticamente nos processos judiciais.
} 
Artigo original

Hegemonia - Revista Eletrônica de Relações Internacionais do Centro Universitário Unieuro ISSN: $1809-1261$

UNIEURO, Brasília, número 21, Julho-Dezembro de 2017, pp. 154-194.

como valores supremos de uma sociedade fraterna, pluralista e sem preconceitos. Assim, para que haja um Estado democrático, pautado no ideal de igualdade e uma sociedade sem preconceitos, faz-se necessários a elaboração de políticas públicas como mecanismos de nivelamento dos indivíduos.

O mesmo diploma legal, como observado anteriormente, prevê como um dos objetivos fundamentais do Estado promover o bem de todos, sem preconceitos de origem, raça, sexo, cor, idade e qualquer outra forma de discriminação. Nesse sentido, o Estado pode se utilizar de quaisquer meios para extinguir o preconceito ou discriminação arraigada na sociedade, a fim de promover o bem estar dos indivíduos.

Ao examinar o artigo 3o da Constituição da República, Marco Aurélio Mendes de Farias Mello, ministro do Supremo Tribunal Federal afirmou que há autorização constitucional para as Ações Afirmativas, senão vejamos:

primeiro, construir - preste-se atenção a esse verbo - uma sociedade livre, justa e solidária; segundo, garantir o desenvolvimento nacional - novamente temos aqui o verbo a conduzir, não a uma atitude simplesmente estática, mas a uma posição ativa; erradicar a pobreza e a marginalização, e reduzir as desigualdades sociais e regionais; e, por último, no que nos interessa, promover o bem de todos, sem preconceitos de origem raça, sexo, cor, idade e quaisquer outras formas de discriminação. Pode-se afirmar, sem receio de equívoco, que se passou de uma igualização estática, meramente negativa, no que se proibia a discriminação, para uma igualização eficaz, dinâmica, já que os verbos "construir, "garantir", "erradicar" e "promover" implicam, em si, mudança de óptica, ao denotar “ação”. Não basta não descriminar. É preciso viabilizar - e encontramos, na Carta da República, base para fazê-lo - as mesmas oportunidades". ${ }^{25}$

25 Discurso proferido pelo Ministro Marco Aurélio no seminário Discriminação e Sistema Legal Brasileiro, em 20 de novembro de 2001, promovido pelo Tribunal Superior do Trabalho. Disponível em: $<\mathrm{http}: / /$ racismonao.org/index.php?option=com_content\&task=view\&id=24\&Itemid=28\&limit=1\&li mitstart= $1>$. Acesso em: 15 de outubro de 2008. 
Artigo original

Hegemonia - Revista Eletrônica de Relações Internacionais do Centro Universitário Unieuro ISSN: $1809-1261$

UNIEURO, Brasília, número 21, Julho-Dezembro de 2017, pp. 154-194.

Tal assertiva revela a necessidade de transformação social através da implementação das ações positivas para igualar ou amenizar o tratamento discriminatório dado pela sociedade os grupos inferiorizados. Ademais, as referidas ações não são imprescindíveis apenas para os grupos marginalizados, mas para que o Estado possa cumprir o seu papel democrático, na busca pela justiça e pela igualdade de todos.

A partir daí nota-se, os princípios são de crucial importância por constituírem a base de aplicabilidade das normas aos casos concretos, existentes no ordenamento jurídico. No dizer de ALVIM: "os princípios proporcionam equilíbrio ao sistema jurídico, ocupam posição no ápice da pirâmide normativa e são consideradas a norma das normas, e também fonte das fontes ${ }^{-26}$

Ademais, os princípios podem ser encontrados de forma implícita ou explícita, todavia tem o mesmo valor, pois o que deve ser verificado é a sua abrangência. Para J. J. Gomes Canotilho, o princípio da igualdade é "um dos princípios estruturantes do regime geral dos direitos" O princípio da igualdade ou isonomia, assentado na Constituição da República, encontra amparo principiológico na Declaração de Direitos do Homem e do Cidadão, o qual revela: "Os homens nascem e são livres e iguais em direitos ${ }^{-27}$

É sabido que a lei não pode ser utilizada para obtenção de privilégios ou perseguições, mas como mecanismo regulador da vida social para tratar todos os cidadãos de maneira justa. ${ }^{28}$

${ }^{26}$ LVIM. Márcia Cristina de Souza. A força normativa do Princípio da Dignidade da Pessoa Humana”. Revista Mestrado em Direito/UNIFIEO - Centro Universitário FIEO. Ano 4, n. 4, 2001.Osasco: EDIFIEO, 2004, p. 17.

27 ORGANIZAÇÃO DAS NAÇÕES UNIDAS. Declaração de Direitos do Homem e do Cidadão. Disponível em: <http://www.direitoshumanos.usp.br/counter/Doc_Histo/texto/Direitos_homem_cidad.html>. Acesso em: 23 de setembro de 2008.

${ }^{28}$ MELLO. Antônio Bandeira de. O Conteúdo jurídico do Princípio de Igualdade“" Ed. São Paulo: Malheiros Editores, 2008, p.10. "A lei não deve ser fonte de privilégios ou perseguições, mas instrumento regulador da vida social que necessita tratar equitativamente todos os cidadãos. Este é o conteúdo político-ideológico absorvido pelo princípio da isonomia e juridicizado pelos textos constitucionais em geral, ou de todo mundo assimilado pelos sistemas normativos vigentes". 
Artigo original

Hegemonia - Revista Eletrônica de Relações Internacionais do Centro Universitário Unieuro ISSN: $1809-1261$

UNIEURO, Brasília, número 21, Julho-Dezembro de 2017, pp. 154-194.

Urge ressaltar entendimento de Celso Antônio Bandeira de Mello, o qual acredita que a igualdade possui dois objetivos. O primeiro, oportunizar garantia individual de forma a impedir quaisquer tipos de perseguições, o segundo, evitar qualquer forma de favoritismo.

Coaduna com os conceitos doutrinários supracitados, a jurisprudência pátria do Supremo Tribunal Federal, ressaltando que: "O princípio isonômico revela a impossibilidade de desequiparaçoes fortuitas ou injustificadas ${ }^{* 29}$

Assim, desse princípio, pode-se extrair três vertentes, quais sejam a igualdade formal, referente à igualdade perante a lei, a igualdade material, referente ao ideal de justiça social e distributiva, e a igualdade material pertinente ao ideal de justiça social como reconhecimento de identidades, norteada pelos critérios de gênero, orientação sexual, raça, idade, etnia e outros critérios. $^{30}$

Nesse sentido, a igualdade entre os indivíduos é premissa para a garantia do respeito a dignidade da pessoa humana, pois o homem não pode ser submetido a tratamento discriminatório e arbitrário, assim não podem ser aceitos a escravidão, a discriminação racial, perseguições por motivo de origem, sexo, e quaisquer tipos de violação do principio da igualdade no aspecto formal ou material. ${ }^{31}$

A Constituição Federal de 1988 consignou o princípio da dignidade da pessoa humana como um Direito Fundamental da República Federativa do Brasil, em seu art. 1o, inciso III. Nessa esteira, a dignidade da pessoa humana constitui o alicerce de todos os direitos fundamentais (civis, políticos e sociais), indispensável para a ordem social. Além de proteger a vida, sobretudo a integridade física e moral do individuo.

${ }^{29}$ BRASIL. SUPREMO TRIBUNAL FEDERAL. 2a Turma. Agravo de Instrumento no 207.130-1 - 2a Turma - Rel. Min. Marco Aurélio, publicado no Diário da Justiça, Seção I, 3, abril, 1998, p.45.

${ }^{30}$ PIOVESAN. Flávia. Ações Afirmativas da Perspectiva dos Direitos Humanos. . Faculdade de Direito e Programa de PósGraduação da Pontifícia Universidade Católica. Cadernos de Pesquisa, v. 35, n.124, jan./abr. 2005. p.5.

31 SARLET. Ingo Wolfgang. Dignidade da Pessoa Humana e direitos fundamentais. Porto Alegre:

Livraria do Advogado. 2001, p. 89 
Artigo original

Hegemonia - Revista Eletrônica de Relações Internacionais do Centro Universitário Unieuro ISSN: $1809-1261$

UNIEURO, Brasília, número 21, Julho-Dezembro de 2017, pp. 154-194.

Nesse caminhar, José Afonso da Silva vislumbra a dignidade da pessoa humana como um valor superior norteador de todos direitos fundamentais do homem, desde o direito primordial a vida. ${ }^{32}$

Logo, a dignidade da pessoa humana engloba direitos ligados a aptidão da pessoa, incluindo direitos individuais e pessoais, e os direitos coletivos, inerentes aos direitos sociais, econômicos e culturais.

O princípio da dignidade da pessoa humana manifesta-se na Constituição da República, ao proibir preconceito por motivo de origem, raça, sexo, idade, cor, credo e outras formas de discriminação; ao vedar a tortura, o tratamento desumano e degradante; ao punir a discriminação atentatória aos direitos e liberdades fundamentais; ao prever a prática de racismo como crime inafiançável e imprescritível, sujeitando o infrator a pena de reclusão, dentre outros. ${ }^{33}$

A dignidade humana é um direito intangível, devendo o Poder Público inibir a violação da integridade do individuo, o é também indisponível, porquanto nenhum individuo pode renunciar ou dispor de direitos relacionados à sua pessoa. Imperioso salientar, o princípio retro implica dois aspectos, um negativo, veda ato estatal atentatório a dignidade do indivíduo, outro positivo, impõe o dever ao Estado de promover a dignidade por meio de condutas ativas.

Contudo, diante dos posicionamentos vistos anteriormente, forçoso concluir que as ações afirmativas estão fundamentadas também no princípio da dignidade da pessoa humana, levando em consideração que o Estado deve promover condições que favoreçam a vida digna do individuo, com a promoção de políticas inclusivas que ao menos amenizem as diferenças sociais.

32 SILVA. De Plácido e. Vocabulário Jurídico. 15a ed. Rio de Janeiro: Forense, 1998, p.526.

33 BRASIL. Constituição (1.988). Art. 3o, inciso IV e art. 5o, incisos III, X, XLI, XLII, CF. 
Artigo original

Hegemonia - Revista Eletrônica de Relações Internacionais do Centro Universitário Unieuro ISSN: $1809-1261$

UNIEURO, Brasília, número 21, Julho-Dezembro de 2017, pp. 154-194.

AÇOES AFIRMATIVAS NO ORDENAMENTO JURÍDICO BRASILEIRO

Hodiernamente, no ordenamento jurídico brasileiro tem sido implementadas ações afirmativas infraconstitucionais, em virtude da não previsão expressa de cunho constitucional, destacando-se duas formas de ações afirmativas, a saber, a ação afirmativa de gênero e a de raça. A Ação Afirmativa de Gênero encontra seu fundamento constitucional no que tange à igualdade entre homens e mulheres, dentre estes, a defesa do mercado de trabalho e poderes iguais no âmbito familiar.

As referidas ações encontram guarida também na Convenção sobre a Eliminação de todas as formas de Discriminação contra as mulheres, que ordena aos Estados propor meios eficazes para a inserção de políticas voltadas a combater a discriminação contra as mulheres. Um exemplo de ações positivas implantadas com vistas a equiparação entre homens e mulheres foi a Lei $n^{\circ} .9 .504 / 97$ que prevê junto aos partidos políticos a reserva de no mínimo 30 por cento e o máximo de 70 por cento para candidatura de cada sexo.

Apesar de esta lei não ser respeitada e não alcançar a eficácia desejada constitui um grande avanço para o direito brasileiro. A primeira experiência eleitoral, restrita ao âmbito municipal, mostrou a eficácia prática da referida norma. Apesar dos resultados terem sido satisfatórios, ainda há grande diversidade entre os sexos. No estado da Paraíba, onde ocorreu o maior número de participação feminina, os registros não passam de 19, 44\%.

Na segunda experiência eleitoral com cotas no âmbito nacional, esta foi desastrosa tendo, em vista a diminuição em 12 por cento do número de mulheres eleitas na Câmara dos Deputados e a permanência do mesmo número no Senado. Porém com relação aos Estados a representação junto às Assembleias Legislativas cresceu mais de 33 por cento.

Dentre as ações positivas inseridas no ordenamento jurídico brasileiro que reconhecem o direito a diferença de tratamento a certos grupos, além dos citados, destaca-se também: 
Artigo original

Hegemonia - Revista Eletrônica de Relações Internacionais do Centro Universitário Unieuro ISSN: $1809-1261$

UNIEURO, Brasília, número 21, Julho-Dezembro de 2017, pp. 154-194.

- o art. 354 da Consolidação das Leis Trabalhistas prevê cotas de dois terços de brasileiros para empregados de empresas individuais ou coletivas;

-a Lei 8.112/90, art. 5o, \20, que garante cotas de até 20 por cento para os portadores d - a Lei 8.213/91, art.93, que fixou cotas para portadores de deficiência no setor privado;

- a Lei 8.666/93, art. 24, XX, que preceitua sobre a inexigibilidade de licitação para contratação de associação filantrópicas, de portadores de deficiência.

Ademais, existe uma medida de igualdade proibidora da discriminação, não é propriamente ação afirmativa. Foi criada pelo legislador pátrio, através da Lei no. 9.799/99, que acrescentou o art. 373-A na Consolidação das Leis Trabalhistas, com o escopo de adotar medidas destinadas a corrigir distorções decorrentes das desigualdades existentes entre homens e mulheres.

Por outro lado, a Ação Afirmativa de Raça constitui objeto do presente estudo, surgiu em virtude do histórico escravocrata carregado pelos afro-descendentes, mesmo após a abolição e da dificuldade de inclusão destes no mercado de trabalho por falta de melhores condições sociais e econômicas.

Essas ações atingiram seu ápice em decorrência de vários estudos estatísticos divulgados, relativos à divergência de condições socioeconômicas entre indivíduos brancos e afrodescendentes, sobretudo com o estudo realizado pelo Instituo de Pesquisa Econômica Aplicada, conforme vislumbrado no referente às deficiências no serviço público civil da união;

\section{O SISTEMA DE COTAS DE ACESSO À UNIVERSIDADE}

O sistema de cotas é uma espécie do gênero Ação Afirmativa, constitui a segunda etapa das referidas ações, e tem por escopo combater o preconceito e discriminação arraigados na sociedade.

A política de cotas surgiu nos Estados Unidos da América, onde se deu o marco inicial das Ações Afirmativas, conforme analisado no capítulo anterior. As cotas ganharam ênfase em 
Artigo original

Hegemonia - Revista Eletrônica de Relações Internacionais do Centro Universitário Unieuro ISSN: $1809-1261$

UNIEURO, Brasília, número 21, Julho-Dezembro de 2017, pp. 154-194.

decorrência da ineficácia de alguns métodos na luta contra a discriminação, e foi contemplada

de maneira ampla na busca da realização da igualdade de oportunidades através da implementação desse sistema.

Conforme foi estudado no segundo capítulo, existem outros meios para efetivação das ações positivas. Destarte, as cotas e outras espécies de ações afirmativas são dois mecanismos primordiais que servem de instrumento para propiciar a inserção do afro-brasileiro na sociedade.

Assim, vislumbramos que as cotas, através de reserva de vaga no vestibular para ingresso nas universidades ou percentagem de empregos para certos grupos, por si só não resolvem o problema da discriminação e marginalização dos afro-descendentes na sociedade brasileira. Devem ser aliadas a bolsas de estudo, reforço escolar, programas especiais de treinamento, cursinhos pré-vestibulares, dentre outros.

As ações positivas não são disseminadas na sociedade, em virtude do risco de ocorrer a discriminação reversa por aplicar o critério de cotas. Outrossim, se fossem implementados mecanismos não utilizadores das cotas, as referidas ações lograriam êxito. ${ }^{34}$

Kauffman demonstra alguns exemplos de utilização das metas como mecanismo de redução das desigualdades raciais sem efeitos de discriminação reversa, tais como: contratação de maior número de pessoas negras por empresas, aumento da quantidade de estudantes negros aliado a delimitação do nível a ser alcançado, dentre outros

Assim, denota-se a problemática existente no sistema de cotas, e a viabilidade para a garantia da eficácia das ações afirmativas através do sistema de metas. Urge salientar, existem outras espécies de ação afirmativa que detém caráter distributivo dotada de cunho assistencial, como

\footnotetext{
34 A expressão discriminação reversa gera controvérsias. Pode ser utilizado para demonstrar que as ações afirmativas podem atingir de forma indireta, indivíduos não merecedores dessa política, como é utilizado no presente trabalho. E também para designar a própria ação afirmativa, como entendem alguns autores.
} 
Artigo original

Hegemonia - Revista Eletrônica de Relações Internacionais do Centro Universitário Unieuro ISSN: $1809-1261$

UNIEURO, Brasília, número 21, Julho-Dezembro de 2017, pp. 154-194.

bolsa para estudantes, preparação para emprego e cursos pré-vestibulares, os quais não geram a discriminação reversa.

O sistema de cotas para o ingresso nas Universidades, não foi eficaz nos Estados Unidos e caiu em desuso, em decorrência da maioria dos juristas o vislumbrar como programa ilegítimo para tal medida, e ter sido taxado como inconstitucional.

Contudo verifica-se, adversamente do ordenamento jurídico norte- americano, o qual adota o sistema de metas, no Brasil, a política de cotas, ainda em vigor, foi recepcionada imbuída de divergências quanto aos aspectos negativos e positivos, porém tem sido implantada de forma pontual em algumas universidades do país.

Os primeiros rumores quanto à adoção do sistema de cotas no ordenamento pátrio, deram-se no estado do Rio de Janeiro com as Leis Estaduais nos. 3.524/ 00, 3.708/ 01 e 4.061/ 03. Essas leis reservaram 50\% (cinquenta por cento) do total de vagas disponíveis junto as Universidades Públicas Fluminenses, para alunos que cursaram o ensino fundamental e médio em escolas públicas municipais ou estaduais, e desse percentual, 40\% (quarenta por cento) para candidatos que se declararem negros ou pardos e 10 por cento a portadores de deficiência.

Entretanto, foi interposta Ação Declaratória de Inconstitucionalidade de no. 2.858, em desfavor de alguns dispositivos das referidas Leis, pela Confederação Nacional dos Estabelecimentos de Ensino, sob o seguinte argumento:

Com a aplicação das três leis aos vestibulares de acesso às universidades públicas do Rio de Janeiro, os candidatos que não se declararem negros ou pardos e que não tenham estudado em escolar pública municipal ou estadual, só poderão concorrer a 30 por cento das vagas oferecidas..$^{35}$

35 LENZA, Pedro. Direitos Constitucional Esquematizado. 8ed. São Paulo: Método, 2005, p. 473. 
Artigo original

Hegemonia - Revista Eletrônica de Relações Internacionais do Centro Universitário Unieuro ISSN: $1809-1261$

UNIEURO, Brasília, número 21, Julho-Dezembro de 2017, pp. 154-194.

Segundo o parecer da Procuradoria Geral da República as leis cariocas eram inconstitucionais em virtude de invadirem a competência privativa da União para legislar sobre diretrizes e bases da educação nacional e, em decorrência da competência concorrente da União para estabelecer normas gerais, consoante artigo 22, inciso XXIV, e artigo 24, inciso IX, da Constituição da República, respectivamente.

Por fim, o Supremo Tribunal Federal não se posicionou sobre o tema, pois o pedido não teve viabilidade, e a ação foi declara prejudicada em decorrência da promulgação da Lei no. 4.151, de 5 de setembro de 2003, que revogou as Leis impugnadas.

Todavia, a política de cotas foi inserida no âmbito federal, através da Medida Provisória $\mathrm{n}^{\circ}$. 213, de 10 de setembro de 2004, que instituiu o Programa Universidade para Todos, posteriormente regulamentada pelo Decreto no. 5.245, de 15 de outubro de 2004. A referida Medida Provisória foi objeto de três Ações Declaratórias de Inconstitucionalidade nos. 3.314, de 4 de outubro de 2004, no. 3.330, de 21 de outubro de 2004 e no. 3.379, de 17 de dezembro de 2004, pendentes de julgamento.

Posteriormente, em 13 de janeiro de 2005, a Medida Provisória foi convertida na Lei no. 11.096, e revogou a Lei no. 10.891, de 9 de julho de 2004, a qual havia instituído a BolsaAtleta, programa destinado a atletas praticantes do desporto de rendimento em modalidade olímpicas e paraolímpicas, vinculadas ao Comitê Olímpico e Paraolímpico Internacional.

A Lei no. 11.096, de 13 de janeiro de 2005, criou o Programa Universidade para Todos, e instituiu status diferenciado para a Educação, a fim de democratizar o acesso ao ensino superior através de contrapartida do Poder Público.

Essa Lei foi destinada a concessão de bolsas de estudos integrais e parciais de 50 ou 25 por cento para estudantes de cursos de graduação em instituições privadas de ensino superior. As integrais beneficiam brasileiros não possuidores de diploma de curso superior com renda 
Artigo original

Hegemonia - Revista Eletrônica de Relações Internacionais do Centro Universitário Unieuro ISSN: $1809-1261$

UNIEURO, Brasília, número 21, Julho-Dezembro de 2017, pp. 154-194.

mensal de até 1 salário- mínimo e meio, já as bolsas parciais, destinam-se a brasileiros não portadores de diploma de curso superior, com renda mensal de até 3 salários-mínimos. ${ }^{36}$

No que tange aos beneficiários do referido programa, serão privilegiados os estudantes concluintes do ensino médio completo em escola da rede pública ou na rede privada, como bolsista integral, a estudantes portadores de deficiência, a professor da rede pública de ensino para os cursos de normal superior e pedagogia, independente da renda mensal, conforme art. 2o da Lei 11.096/ 05.

Ademais, também são beneficiários das cotas de acesso ao ensino superior, as minorias étnicoraciais, quais sejam os negros e indígenas, consoante o art. 7o da referida Lei. Urge ressaltar que as Instituições credenciadas ao Programa Universidade para Todos, detém isenção de impostos e contribuições, quais sejam, Imposto de Renda das Pessoas Jurídicas, Contribuição Social sobre o Lucro Líquido, Contribuição Social para Financiamento da Seguridade Social e Contribuição para o Programa de Integração Social

Do exposto, verifica-se, as ações afirmativas étnico-raciais na modalidade de cotas de que trata a Lei retro mencionada, foi aliada a isenção fiscal destinada às instituições participantes do programa. No entanto, há alguns fatores a serem considerados para a implementação das ações afirmativas e eficácia da Lei no. 11.096/05.

Quanto aos critérios estabelecidos para merecimento das cotas raciais, a lei, apenas menciona a necessidade de auto declaração, na qual o próprio individuo declara sua cor, o que remonta uma série de dúvidas referentes à legitimidade de tal afirmação. É mister salientar a diversidade étnica-racial existente no país, bem como o sistema multirracial brasileiro, dificulta o desenvolvimento de critério legal, lógico e preciso que defina pessoa negra no País.

Não obstante no Brasil, não há classificação racial formalizada em preto e branco, da forma que há nos Estados Unidos, onde através de pensamentos ideológicos descobrem sangue

\footnotetext{
${ }^{36}$ BRASIL. Lei no. 11.096/05. Dispõe sobre a instituição do Programa Universidade para todos, regula a atuação de entidades beneficentes de assistência social no ensino superior, altera a Lei 10.891/04. Art. 1o, \$S 1o e 2 o.
} 
Artigo original

Hegemonia - Revista Eletrônica de Relações Internacionais do Centro Universitário Unieuro ISSN: $1809-1261$

UNIEURO, Brasília, número 21, Julho-Dezembro de 2017, pp. 154-194.

negro em pessoas brancas, que por sua vez, passam a ser taxadas de negra, mesmo portando

caracteres brancos. Em suma, a classificação das categorias raciais no país é utilizado aparência física e status social, porém nos Estados Unidos o critério utilizado é a ancestralidade.

Conforme a Pesquisa Nacional por Amostras de Domicílios, ao ser elaborada uma pergunta subjetiva, de livre resposta, sobre qual a cor dos entrevistados, foram identificados 136 cores no país. Todavia, sob o prisma teórico, a miscigenação aliada ao sistema de autoclassificação, correria o risco de acabar em decorrência da tendência ao branqueamento no Brasil.

Segundo o entendimento de Degler, esse fenômeno pode ser denominado de "válvula de escape do mulato" no qual os negros se casariam com os brancos, e consequentemente haveria um clareamento dos filhos e não seriam mais negros. Porém, esse mecanismo só pode ser utilizado no Brasil, pois nos Estados Unidos o fator determinante para a classificação da cor é a ancestralidade.

Daí verifica-se que o critério da auto declaração da cor trazido a baila para a adoção de ações afirmativas, são medidas geradores de controvérsia devido à miscigenação da população brasileira, conforme revela os dados censitários. Outra polêmica, ainda com relação à auto declaração, refere-se às pessoas que se autodeclarem negras em virtude do meio, a fim de conseguirem o ingresso nas universidades de maneira fácil.

Por outro lado, outro fator a ser considerado para adoção de cotas nas universidades é o número de 40\% (quarenta por cento) das vagas reservadas aos afro-descendentes, e o censo do ano de 2.000 revelou 49\% (quarenta e nove por cento) da população como sendo afrodescendente. Assim, o problema da desigualdade existente no país não seria resolvido por inteiro, pois 9 por cento dos afrodescendentes continuariam na situação de exclusão.

Cabe mencionar que os efeitos sobre a qualidade de ensino com a adoção das cotas, pois com a reserva de vagas, o nível de exigência para aprovação nos vestibulares será reduzido. Aliado às cotas, deveria ser previsto um nível mínimo a ser atingido para a aprovação nos vestibulares, 
Artigo original

Hegemonia - Revista Eletrônica de Relações Internacionais do Centro Universitário Unieuro ISSN: $1809-1261$

UNIEURO, Brasília, número 21, Julho-Dezembro de 2017, pp. 154-194.

e ainda, adotado uma medida de compensação com o acompanhamento de alunos cotistas por grupo de professores.

Nesse contexto, outra questão flagrante com relação à referida lei, é a falta de previsão de bolsa possibilitadora de dedicação integral aos estudos ou até mesmo a garantia de estudo noturno, supondo que os estudantes beneficiados pertencem à parcela pobre da população e necessitam trabalhar para manter os estudos.

Com isso, gera a evasão do curso pelos estudantes afro- descendentes, e a frustração individual dos alunos que continuarem o curso, pois ao concluírem, não terão preparo suficiente para lograr êxito no mercado de trabalho.

A implementação das Ações Afirmativas através do sistema de cotas para o ingresso no ensino superior tem gerado polêmica, pelo fato de inserirem minorias marginalizadas pela sociedade que não possuem recursos suficientes para acesso às Universidades.

Ademais, existe um Projeto de Reforma Universitária, em andamento no Congresso Nacional, no qual prevê a reserva de 50\% (cinquenta por cento) das vagas a cotas. O Ministério da Educação defendeu que as Universidades públicas destinasse 50\% (cinquenta por cento) das vagas para alunos carentes, afro-descendentes e indígenas.

Hodiernamente, a controvérsia sobre a implantação desse sistema foi assentada em torno de três eixos: tratamento desigual decorrente da aprovação de candidato que atingiu nível inferior a de outros; a redução da qualidade de ensino nas universidades e a falsa ideia de democracia racial, a qual encobre o preconceito e discriminação racial existente, alicerçado pela diferença social, considerando apenas o aspecto econômico.

Em virtude da ausência da delimitação de critérios específicos, necessários para aferir o merecimento das cotas de acesso à Universidade, sua implementação ocorreu de forma isolada em alguns pontos do país. A Universidade Estadual do Rio de Janeiro e a Universidade do Estado da Bahia foram pioneiras e suscitaram grande polêmica com a adoção dessas medidas. 
Artigo original

Hegemonia - Revista Eletrônica de Relações Internacionais do Centro Universitário Unieuro ISSN: $1809-1261$

UNIEURO, Brasília, número 21, Julho-Dezembro de 2017, pp. 154-194.

O sistema de cotas na referida universidade carioca, reservou 45\% (quarenta e cinco por cento) das vagas da universidade aos cotistas, sendo $20 \%$ (vinte por cento) para alunos da rede pública e 20\% (vinte por cento) para alunos negros e 5\% (cinco por cento) para portadores de deficiência, índios e filhos de policiais, bombeiros e inspetores de segurança mortos em serviço ou incapacitados em razão do trabalho.

Em 2003, no primeiro vestibular dessa instituição, com o sistema de cotas, 36,6\% (trinta e seis vírgula seis por cento) dos alunos aprovados não ingressaram através da reserva de vagas. Atualmente, em mais da metade dos cursos oferecidos pela universidade em epígrafe, há mais reserva de vagas para cotista que candidatos, isso se deve a carência de recursos dos beneficiados para arcar com os estudos.

Outrossim, na Universidade do Estado da Bahia, a reserva de vagas pelo sistema de cotas é de $45 \%$ (quarenta e cinco por cento) das vagas, sendo 40\% (quarenta por cento) destinadas a negros e 5\% (cinco por cento) aos indígenas. Com relação às Universidades Federais, a implantação do sistema de cotas ocorreu tempo depois e a Universidade de Brasília foi a primeira a adotar essa política de inclusão social.

Na Universidade de Brasília, a política de cotas reservou 20\% (vinte por cento) das vagas a candidatos negros, e estabelece uma serie de requisitos que serão analisados posteriormente. Assim, aos poucos o sistema de cotas expandiu em meio as Universidades Federais do país, e cada instituição, conforme as necessidades da região em que localizam, destinaram as reservas de vagas a candidatos carentes, afro-descendentes e indígenas.

Algumas instituições localizadas no norte e centro-oeste do país ofereceram mais vagas para os indígenas, outros no norte e nordeste destinam mais vagas a negros, no sul do país para deficientes, outras concedem isenção da taxa de inscrição, e algumas estão em fase de implementação e ainda, existem instituições que não planejam instituir cotas. Existem 56 universidades federais distribuídas em todo o país, porém apenas 20 aderiram ao sistema de cotas. 
Artigo original

Hegemonia - Revista Eletrônica de Relações Internacionais do Centro Universitário Unieuro ISSN: $1809-1261$

UNIEURO, Brasília, número 21, Julho-Dezembro de 2017, pp. 154-194.

Essa diversidade, quanto à aplicação do sistema de cotas, só é possível em decorrência da autonomia universitária, no qual as instituições de ensino aplicam a reserva de vagas conforme decisão do Conselho Universitário.

Com isso, alguns critérios provocam polêmica como aconteceu na Universidade Federal do Paraná, a qual reserva 20\% (vinte por cento) das vagas para estudantes de cor preta ou parda possuidores de fenótipos caracterizadores do grupo racial negro. Assim, após a aprovação do candidato autodeclarado negro, o submete a banca de avaliadores e o examinam para verificar se realmente possuem características de afro-descendentes.

Recentemente, a imprensa noticiou um caso ocorrido na Universidade de Brasília, pertinente ao sistema de cotas que gerou bastante discussão. Dois irmãos gêmeos idênticos candidataramse a vaga para o curso de graduação, através do sistema de cotas, mas um deles teve sua inscrição deferida e o outro não. Assim, o gêmeo que teve sua inscrição rejeitada, após interpor recurso pôde concorrer à vaga por meio das cotas.

A política de cotas para acesso no ensino superior foi já implantada na Universidade Federal de Goiás, e sua primeira experiência foi no vestibular de 2.009. Para implementação do sistema de cotas, foi criado o programa UFGInclui, voltado a inclusão de alunos pertencentes a grupos marginalizados pela sociedade.

A reserva de cotas é de 40\% (quarenta por cento), sendo 20\% (vinte por cento) para candidatos de escolas públicas e $20 \%$ (vinte por cento) para negros e indígenas. Nota-se que são utilizados dois critérios, o econômico, pois beneficia alunos de parcos recursos, provenientes de escolas públicas e o critério racial, destinado negros, indígenas e negros quilombolas.

Conforme o programa da época, para o candidato concorrer à vaga como negro é necessário apenas auto declaração. No caso do índice de aprovados pelo programa de cotas não atingir 10\% (dez por cento), serão convocados os candidatos segundo a ordem de classificação, até atingir o percentual. O referido programa adotado pela universidade em epígrafe terá validade 
Artigo original

Hegemonia - Revista Eletrônica de Relações Internacionais do Centro Universitário Unieuro ISSN: $1809-1261$

UNIEURO, Brasília, número 21, Julho-Dezembro de 2017, pp. 154-194.

mínima de 10 anos, e sempre sofrerá avaliação para eventuais alterações pelo Conselho Universitário. A Universidade Federal de Goiás, é a única universidade pública brasileira que tem seu corpo docente formado por 1,2\% (um vírgula dois por cento) de professores negros.

Imperioso, verificar se o problema da exclusão social enfrentada pelos afro-descendentes decorre da discriminação racial, referente à cor da pele, ou está aliado a outros fatores, como a classe social, a fim promover propostas assertivas para a aplicação eficiente da Lei. O Brasil não é modelo de democracia racial, porém, o racismo não foi determinante para impedir a constituição de uma sociedade plural, diversa e miscigenada, pois os valores nacionais muito se identificam com valores negros

Outrossim, a crescente ascensão dos afro-descendentes na televisão, em propagandas, como protagonistas de novelas, encenando papéis de classe média, alta; em concursos de beleza, demonstram que o ideal de ao aparência no Brasil está modificando, seguindo o exemplo de valorização mundial dos afro-descendentes. Vale salientar ainda, o surgimento de produtos de beleza específicos para afro-descendentes denotam poder aquisitivo dos mesmos.

Em suma, a adoção de ações afirmativas pautadas no único critério racial, poderá criar dois polos sociais, o primeiro dos beneficiados pelo programa, e o segundo dos não beneficiados, além de atingir o equilíbrio racial no país. É flagrante, os afro-descendentes possuem condição social inferior a dos brancos, conforme os indicadores sociais estudados anteriormente.

Contudo, a discriminação racial pode não ser determinante para esse indicativo, mas a precária condição financeira, a qual os torna menos preparados para o ingresso nas universidades. Segundo Kauffman, as ações afirmativas implantadas no Brasil devem obedecer ao binômio: raça e pobreza, pois dessa forma atingiria as duas mazelas principais que inibem os afrodescendentes de conseguirem posição elevada

Nesse sentido, vislumbra-se o gravame em implantar políticas alicerçadas apenas no critério racial, sem junta-las com o critério baixa renda, o que consequentemente geraria o beneficiamento da classe média afro- descendente, não carente desse benefício. Por outro lado, 
Artigo original

Hegemonia - Revista Eletrônica de Relações Internacionais do Centro Universitário Unieuro ISSN: $1809-1261$

UNIEURO, Brasília, número 21, Julho-Dezembro de 2017, pp. 154-194.

se o critério para merecimento das cotas fosse apenas o da baixa renda, os brancos carentes tirariam proveito em virtude dos indicadores sociais serem mais elevados que dos negros.

Urge ressaltar, os negros integram um ciclo vicioso, estudam em escolas públicas por não terem condições de pagar um ensino de mais qualidade, consequentemente ficam despreparados para o ingresso em uma instituição de ensino superior de qualidade, e desqualificados para o mercado de trabalho. Com isso, vislumbramos que não é apenas a cor da pele a causa da marginalização dos afro-descendentes na sociedade.

É mister salientar, a questão da sub-representatividade dos negros na sociedade está ligada a condição econômica, pois na escolha das profissões são selecionadas as de baixo investimento financeiro, com relação as mensalidades ou o material gasto durante o curso. Para exemplificar, vejamos o que foi noticiado pelo Exame Nacional de Cursos, realizado pelo Ministério da Educação e Cultura, em 2002.

O curso de Medicina, Medicina Veterinária e Odontologia, os quais necessitam de alto investimento financeiro, detém representação dos negros em torno de menos de 15\% (quinze por cento), no primeiro, e menos de 10\% (dez por cento) nos dois últimos.

Outrossim, nos cursos de menor investimento, com mensalidade mais baratas, como História, a representação de negros é de 38\% (trinta e oito por cento), no curso de Letras, 29\% (vinte e nove por cento) e no de Matemática, 33\% (trinta e três por cento). A exceção é o curso de Direito, no qual é praticamente teórico e a representatividade é de apenas 14\% (quatorze por cento).

Tais afirmações demonstram o critério econômico não pode ser desconsiderado para a adoção das políticas afirmativas para ingresso nas Universidades, pois é relevante para a determinação dos beneficiários. Por fim, é forçoso destacar a importância da Lei 11.096/05 para a inclusão social das minorias étnicas e raciais existentes no país. 
Artigo original

Hegemonia - Revista Eletrônica de Relações Internacionais do Centro Universitário Unieuro ISSN: $1809-1261$

UNIEURO, Brasília, número 21, Julho-Dezembro de 2017, pp. 154-194.

Ademais, a delimitação de critérios que efetivamente cumpram o objetivo real dessas ações, necessita ser constituído do binômio retro mencionado, qual seja a raça e a renda, a fim de exterminar a desigualdade racial, social e econômica existente no país.

\section{CONSIDERAÇOES FINAIS}

Do presente trabalho, depreende-se que os afro-descendentes carregam o duro fardo da escravidão, mesmo não sendo mais submetidos a tratamento desumano e degradante como nos velhos tempos.

Nesse sentido, é inegável a existência da discriminação racial em face dos afro-descendentes no país, decorrente do histórico vivido. Encobrir esse racismo com o mito da democracia racial é ironia, diante dos indicadores analisados.

A discriminação contra os afro-descendentes, gera sua exclusão social, e revelam a desigualdade social, profissional, intelectual, preponderantes para a diferença econômica no Brasil atual.

Com isso, vislumbra-se a imprescindibilidade da adoção das ações afirmativas objetivando a inserção das minorias economicamente carentes, ou inferiorizadas racialmente, nas universidades públicas e privadas.

Ademais, a Convenção Internacional sobre a eliminação de todas as formas de discriminação racial, na qual o Brasil é signatário, reafirmou os ideais de redução das desigualdades sociais.

As referidas ações encontram assento na Constituição da República, como objetivo do Estado democrático de direito, destinado a assegurar a igualdade, ligada à ideia de promoção de medidas para a igualação dos indivíduos desiguais, constituindo-a como valor supremo de uma sociedade sem preconceitos.

Dentre os fundamentos do Estado, está a dignidade da pessoa humana, referente à proteção da vida, englobando os direitos civis, políticos e sociais, bem como a integridade física e moral do individuo. 
Artigo original

Hegemonia - Revista Eletrônica de Relações Internacionais do Centro Universitário Unieuro ISSN: $1809-1261$

UNIEURO, Brasília, número 21, Julho-Dezembro de 2017, pp. 154-194.

No ordenamento jurídico brasileiro, destacam-se duas formas de ação afirmativas, a de gênero e a de raça, a primeira, defende a isonomia entre homens e mulheres em diversos âmbitos, já a segunda, diz respeito a igualdade de oportunidades para os grupos marginalizadas em decorrência da raça pertencente.

Todavia, as ações positivas na modalidade de cotas têm despertado inúmeras controvérsias entre os doutrinadores, e na maioria a vislumbram como o remédio errado para a doença certa, ou seja, há necessidade de adoção das políticas para inserção dos afro-descendentes nas camadas mais elevadas da sociedade, porém a modalidade de cotas não é ideal para a consecução dos objetivos.

Justifica-se no fato das cotas, reservarem um percentual determinado para indivíduos pertencentes a raças inferiorizadas, causando a discriminação reversa dos não beneficiados.

Assim, o sistema de metas, o qual visa a realização futura de determinada proporção de negros para brancos, e é extinta no momento do alcance de seus objetivos, seria mais adequado para a garantia da eficácia dessa política, sem gerar a discriminação reversa.

No que tange a Lei 11.096/05, a qual institui a reserva de vagas para as minorias étnico-raciais, negros e indígenas, para alunos oriundos de escolas públicas ou privadas, na condição de bolsistas, a professores da rede pública de ensino para os cursos de normal superior e pedagogia, é de difícil aplicação prática, em virtude da falta de delimitação de critérios mais específicos.

Para ser beneficiário das cotas para negros, necessita apenas de auto declaração do candidato. A falta de critérios faz as universidades aplicarem métodos estabelecidos através de Conselhos Universitários, remontando a uma miscelânea de regras que divergem em todo o país.

Destarte, além do critério racial utilizado para merecimento das cotas, é imperioso a inserção de critério econômico, senão irá beneficiar os afro- descendentes da classe média brasileira. 
Artigo original

Hegemonia - Revista Eletrônica de Relações Internacionais do Centro Universitário Unieuro ISSN: $1809-1261$

UNIEURO, Brasília, número 21, Julho-Dezembro de 2017, pp. 154-194.

Ademais, aliado ao critério racial e econômico, imprescindível a utilização de outros, como bolsas de estudos para os beneficiários se dedicarem integralmente aos estudos, ajuda de custo para arcar com o ônus de materiais gastos durante o curso, acompanhamento extra dos professores, para duvidas e auxilio, dentre outros.

Contudo, para a aplicabilidade do programa de ações afirmativas nas Universidades brasileiras, imprescindível descartar as cotas como método de ingresso no Ensino Superior. Todavia, é salutar a adoção do programa de metas, aliado ao critério racial e econômico para o alcance das duas mazelas alvejadas pela exclusão social no país, os afro-descendentes e os carecedores de recursos.

\section{BIBLIOGRAFIA}

ALVES, Cléber Francisco. O princípio Constitucional da Dignidade da Pessoa Humana: o enfoque da doutrina social na Igreja. Rio de Janeiro: Renovar, 2001

ALVIM, Márcia Cristina de Souza. A Força normativa do Principio da dignidade da pessoa humana. Revista do Mestrado em Direito/UNIFIEO - Centro Universitário FIEO. Ano 4, 2001. Osasco: EDIFIEO, 2004.

BELLO. Enzo. Periódico n 26. Políticas Públicas para a População negra no Brasil. Rio de Janeiro: Pontifícia Universidade Católica - Departamento de Direito, janeiro-junho, 2005. p. 37.

BRASIL. Constituição (1988). Preâmbulo.

BRASIL. Lei no. 11.096/05. Dispõe sobre a instituição do Programa Universidade para todos, regula a atuação de entidades beneficentes de assistência social no ensino superior, altera a Lei

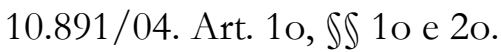

BRASIL. SUPREMO TRIBUNAL FEDERAL. 2a Turma. Agravo de Instrumento no 207.130-1 - 2a Turma - Rel. Min. Marco Aurélio, publicado no Diário da Justiça, Seção I, 3, abril, 1998, p.45.

Convenção Internacional sobre a Eliminação de Todas as formas de Discriminação Racial. Disponível em: $<$ 
Artigo original

Hegemonia - Revista Eletrônica de Relações Internacionais do Centro Universitário Unieuro ISSN: $1809-1261$

UNIEURO, Brasília, número 21, Julho-Dezembro de 2017, pp. 154-194.

http://www.mj.gov.br/sedh/ct/legis_intern/conv_int_eliminacao_disc_racial.htm>

Acesso em: 02 de setembro de 2008.

DIÁRIO DO VALE. Argentino teria assumido declarações racistas. São Paulo. Diário On Line Esporte. Disponível em:<http://www.diarioon.com.br/arquivo/4036/esportes/esportes32531.htm>. Acesso em: 18 de setembro de 2008.

O ESTADO DE SÃO PAULO. Negros serão maioria já em 2008, diz Instituto de Pesquisa Econômica e Aplicada. São Paulo: 14 de $\mathrm{m}$ aio de 2008. Disponível em:<http://pfdc.pgr.mpf.gov.br/clipping/maio/negros-serao-maioria-no-pais-ja-em-2008diz- ipea/>. Acesso em: 16 de setembro de 2008.

GOMES. Joaquim Benedito Barbosa. Ação Afirmativa e principio Constitucional da Igualdade. Rio de Janeiro : Renovar, 2001. p. 20.

FERREIRA, Ricardo Franklin. Afro-descendente: identidade em construção. São Paulo: Educ e Rio de Janeiro: Pallas, 2004, p. 50.

FERNANDES. Florestan. BRASIL. Campinas: Universidade Estadual de Campinas, Núcleo de Estudos de População. 1.986. p. 59. $\square$ Idem, ibidem.

LENZA, Pedro. Direitos Constitucional Esquematiąado. 8ed. São Paulo: Método, 2005, p. 473.

LVIM. Márcia Cristina de Souza. A força normativa do Princípio da Dignidade da Pessoa Humana.. Revista Mestrado em Direito/UNIFIEO - Centro Universitário FIEO. Ano 4, n. 4, 2001.Osasco: EDIFIEO, 2004, p. 17.

MENEZES. Paulo Lucena de. A Ação Afirmativa. (Affirmative Action) no Direito NorteAmericano. São Paulo: Revista dos Tribunais, 2001. p. 30.

MARCO AURÉLIO Discurso proferido pelo no seminário Discriminação e Sistema Legal Brasileiro, em 20 de novembro de 2001, promovido pelo Tribunal Superior do Trabalho. Disponível em: $<$ http: $/ /$ racismonao.org $/$ index.php?option $=$ com_content\&task $=$ view\&id $=24 \&$ Itemid $=28 \&$ limit=1\&li mitstart=1> . Acesso em: 15 de outubro de 2008.

MELLO. Antônio Bandeira de. O Conteúdo jurídico do Princípio de Igualdade" Ed. São Paulo: Malheiros Editores, 2008, p.10.

NOGUEIRA, Oracy. Tanto Preto quanto branco etudi de Relações Raciais. São Paulo: T. A. Queiroz. 1.985. pp. 67-93. 
Artigo original

Hegemonia - Revista Eletrônica de Relações Internacionais do Centro Universitário Unieuro ISSN: $1809-1261$

UNIEURO, Brasília, número 21, Julho-Dezembro de 2017, pp. 154-194.

PIOVESAN. Flávia. Ações Afirmativas da Perspectiva dos Direitos Humanos. . Faculdade de Direito e Programa de Pós-Graduação da Pontifícia Universidade Católica. Cadernos de Pesquisa, v. 35, n.124, jan./abr. 2005. p.5.

PINSKY. Jaime. A escravidão no Brasil. 18a ed. São Paulo: Contexto, 2001, p. 11

ORGANIZAÇÃO DAS NAÇÕES UNIDAS. Declaração de Direitos do Homem e do Cidadão.

Disponível

em:<http://www.direitoshumanos.usp.br/counter/Doc_Histo/texto/Direitos_homem_cid ad.html>. Acesso em: 23 de setembro de 2008.

SARLET. Ingo Wolfgang. Dignidade da Pessoa Humana e direitos fundamentais. Porto Alegre. Livraria do Advogado. 2001, p. 89

SCHWARTZMAN, Simon. Fora de Foco: Diversidade e Identidades étnicas no Brasil. Novos Estudos CEBRAP, no. 55, pp. 83-96. p. 3, 1999, Disponível em: http://www.schwartzman.org.br/simon/pdf/origem.pdf $>$. Acesso em: 02 de setembro de 2008.

SILVA. Carlos Alberto Figueiredo. Revista Digital Buenos Aires, no 84, 2005. Centro Universitário Augusto Motta. Disponível em:< http://www.efdeportes.com/efd84/racismo.htm> . Acesso em: 18 de setembro de 2008.

SILVA. De Plácido. Vocabulário Jurídico. 15a ed. Rio de Janeiro: Forense, 1998, p.526.

VASCONCELOS. Adriana; TALENTO, Biaggio; FRAGA, Danilo. O Globo. Disponível em:< http://www.adur-rj.org.br/5com/pop-up/declaracao_qi_do_baiano.htm> . Acesso em: 18 de setembro de 2008 . 